\title{
Homeostasis of Metals in Epidermis: Age Shifts and Possible Connection with Critical (Synchronous) Work of Membrane ATPases
}

\author{
VI Petukhov*1, EV Dmitriev ${ }^{2}$, L Kh Baumane ${ }^{3}$ and AV Skalny ${ }^{4}$ \\ ${ }^{1}$ Baltic International Academy, Riga, Latvia \\ ${ }^{2}$ Institute of Numerical Mathematics, Moscow, Russia \\ ${ }^{3}$ Latvian Institute of Organic Synthesis, Riga, Latvia \\ ${ }^{4}$ ANO “Centre for Biotic Medicine", Moscow, Russia \\ *Corresponding author: VI Petukhov, Baltic International Academy, Riga, Latvia
}

\section{ARTICLE INFO}

Received: 蔧 June 22, 2020

Published: 凿 June 26, 2020

Citation: VI Petukhov, EV Dmitriev, L Kh B, AV Skalny. Homeostasis of Metals in Epidermis: Age Shifts and Possible Connection with Critical (Synchronous) Work of Membrane ATPases. Biomed J Sci \& Tech Res 28(3)-2020. BJSTR. MS.ID.004667.

Keywords: Nitric Oxide; Metal Ligand Homeostasis; Self Organized Criticality; Epidermis

\author{
ABSTRACT
}

We performed a statistical analysis on a double logarithmic scale graph of the results of atomic emission spectrometry of hair in 10,000 practically healthy individuals (5,000 men and 5,000 women aged 20 to 45 years) for the content of $\mathrm{Al}, \mathrm{Cd}, \mathrm{Pb}, \mathrm{V}$, $\mathrm{Li}$, and $\mathrm{Cr}$. The analysis allowed us to detect a power-law relationship between the metal content in the epidermis and the number of individuals. We also performed a comparative analysis of the content of metals ( $\mathrm{Na}, \mathrm{K}, \mathrm{Al}, \mathrm{Cd}, \mathrm{Cr}, \mathrm{Cu}, \mathrm{Fe}, \mathrm{Li}, \mathrm{Pb}, \mathrm{V}$ and $\mathrm{Zn}$ ) in three different age groups of healthy subjects (100 subjects per group), including a comparison between two groups of subjects of the same age: one group of liquidators of the Chernobyl accident $(n=58)$ and a control group of practically healthy subjects $(\mathrm{n}=58)$. In the last two groups, along with spectrometry of metals, an EPR analysis of hair was performed to quantify the NO production in this biosubstrate. The evidence obtained in favor of the synchronous (critical) mode of operation of membrane pumps in charge of metal traffic, i.e. ATPases (P-type) gives us grounds to believe that homeostasis of metals in the epidermis is a self-organized criticality phenomenon ('SC phenomenon'). This makes hair spectrometry untenable for assessing the content of any specific metal at whole body level.

Abbreviations: Na: Sodium; K: Potassium; SC: Self-Organized Criticality; MLH: MetalLigand Homeostasis; SI: Synchronization Index; ICP-MS: Inductively Coupled Plasma Mass Spectrometry; PDF: Probability Density Function

\section{Introduction}

The spectrometric analysis of the level of sodium ( $\mathrm{Na}$ ) and potassium $(\mathrm{K})$ in the epidermis derivative (hair), which was performed earlier in 10297 healthy individuals (from 2 to 85 years old), revealed the following age-related features in the homeostasis of these metals [1]. In the extreme age groups (from 2 to 9 years and from 60 to 85 years), there was a significant (almost threefold) increase in the content of $\mathrm{Na}$ and $\mathrm{K}$ as compared with the middle age group (20-49 years). The average concentration values of these metals found using the bootstrap method (since it was not possible to confirm the hypothesis about the normal distribution of spectrometry data), were as follows: for potassium in the extreme age groups - $376.9 \mu \mathrm{g} / \mathrm{g}$ (2-9 years) and $121.4 \mathrm{mcg} / \mathrm{g}(60-85$ years old), and in the group of 20 to 49 year-olds - only $47.1 \mathrm{mcg} / \mathrm{g}$; sodium in the extreme age groups - $324.9 \mu \mathrm{g} / \mathrm{g}(60-85$ years) and $293.9 \mu \mathrm{g} / \mathrm{g}$ (2-9 years), and in the group from 20 to 49 years old only $99.9 \mu \mathrm{g} / \mathrm{g}$. We lean toward attributing such a difference to the increased production of reactive oxygen and nitrogen species (ROS and RNS) in childhood [2] and senile age. 
It is known that ROS and RNS are activators of $\mathrm{Na}^{+}, \mathrm{K}^{+}$-ATPase the main transporter of $\mathrm{Na}^{+}$and $\mathrm{K}^{+}$ions through the plasma membrane. The activation of $\mathrm{Na}^{+}, \mathrm{K}^{+}$-ATPase with ROS (oxidation) and/or RNS (nitrosylation) occurs upon modification of SH-groups of cysteine in the protein molecule of this enzyme. As a result, the density (quantity) of actively working $\mathrm{Na}^{+}$and $\mathrm{K}^{+}$transporters increases on the cell membrane. The use of the term 'density' is not incidental. According to the theory of self-organized criticality (SC) [3], the membrane ATPases pool is a system of oscillators that can be activated by ROS and RNS and 'attune' (synchronize) their own oscillations (given sufficient density of active molecules on the cell membrane), thereby switching to critical condition. Consequently, under conditions of oxidative and/or nitrosative stress with the synchronous operation of membrane pumps, one can expect an increase in the concentration of $\mathrm{Na}^{+}$and $\mathrm{K}^{+}$ions in epidermal cells. We were able to verify the reality of such events by examining metal-ligand homeostasis (MLH) in the epidermis (hair) of 947 healthy individuals and 954 liquidators of the Chernobyl accident [4].

The prooxidant shifts detected in the blood of the liquidators suggested oxidative stress [5], while the results of the EPR analysis of hair (a significant increase in the EPR signal of nitroxide) were indicative of nitrosative stress [6]. The differences revealed in MLH among the Chernobyl liquidators as compared with the control group concerned not only $\mathrm{Na}$ and $\mathrm{K}$ but also such metals as $\mathrm{Ca}, \mathrm{V}, \mathrm{Zn}, \mathrm{Cu}, \mathrm{Cd}, \mathrm{Fe}, \mathrm{Al}, \mathrm{Cr}, \mathrm{Pb}, \mathrm{Li}$ [7]. In addition, another probable discriminator of nitrosative stress was found - the linear correlation coefficient $r$ (Pearson) between the concentration values of $\mathrm{K}$ and $\mathrm{Zn}$, which was 1.5 times higher in the liquidators $\left(r_{\mathrm{K}-\mathrm{Zn}}=-0.42 ; \mathrm{p}<0.05\right)$ than in the control group $\left(r_{\mathrm{K}-\mathrm{Zn}}=-0.28 ; \mathrm{p}<0.05\right)$ [7]. It is possible that a linear K-Zn bond, which becomes closer due to nitrosative stress, may indicate that synchronous (critical) mode of operation is inherent in the entire family of membrane ATPases (P-type), which are responsible for metal traffic (not just $\mathrm{Na}^{+}, \mathrm{K}^{+}$ATPases), although the degree of this 'criticality' and the direction of quantitative shifts (up or down) may be different.

We have discovered the following signs of criticality confirming the fact that metal homeostasis in the epidermis is a phenomenon of self-organized criticality ('SC-phenomenon'). First, the presence of stable linear correlation (regardless of sample size) between the concentration values of $\mathrm{K}$ and $\mathrm{Na}$. The synchronous work of membrane $\mathrm{Na}^{+}, \mathrm{K}^{+}$-ATPases, apparently, should explain the origin of this correlation. Please note that the value of the coefficient $r_{\mathrm{K}}^{-}{ }_{\mathrm{Na}}$ (Pearson), not exceeding 0.6-0.7 in the total sample (if you do not take into account the $\mathrm{Na} / \mathrm{K}$ ratio), increased significantly to 0.8-0.9 with a separate definition of $r_{\mathrm{K}-\mathrm{Na}}$ in groups with $\mathrm{Na}$ / $\mathrm{K}<1$ and $\mathrm{Na} / \mathrm{K}>1$ [8]. At the same time, non-constant (sample size dependent) pairwise linear correlations (both positive and negative) are also found between other metals [9], which does not exclude the possibility of synchronous (critical) operation of their transmembrane transporters (ATPases of P-type). Second, the selforganized criticality in the MLH of the epidermis involves not only the synchronous operation of membrane pumps but also a powerlaw relationship between the number of cells and the metal content in them (in certain ranges of numerical values).

On a graph on a double logarithmic scale, the power-law takes the form of a straight line, which allows this power-law dependence to be identified, and its inherent fractality (independence of scale) enables to identify a power-law dependence at any level which suitable for such analysis. Therefore, if power-law dependence really exists between the number of cells and the content of metals in them, then it should obviously manifest itself not only at the cellular level but also at the level of individuals. This greatly simplifies the research task and, as our experience shows, makes it completely solvable using hair spectrometry. Our analysis of spectrometric data using mathematical statistics methods confirmed the applicability of the power-law for homeostasis of $\mathrm{Na}, \mathrm{K}, \mathrm{Ca}, \mathrm{Fe}, \mathrm{Cu}, \mathrm{Zn}[1,10]$. The results of similar studies of $\mathrm{MLH}$ for such metals as $\mathrm{Al}, \mathrm{Cd}, \mathrm{Pb}, \mathrm{V}, \mathrm{Li}$, $\mathrm{Cr}$, are presented in this paper. Third, the degree of synchronization (criticality) in the functioning of membrane ATPases (P-type) can be measured using the so-called synchronization index (SI), which is equal to the area under the curve of numerical values of pair correlations (Pearson) between metals (without taking into account the sign) [11].

It turned out that the SI value under nitrosative stress (accident liquidators) was not only higher than in the control group (6.13 vs 2.17) but also combined with characteristic shifts in MLH: Al ( $\uparrow), C d$ $(\uparrow)$, Fe $(\uparrow), \operatorname{Cr}(\uparrow), \operatorname{Cu}(\downarrow), \operatorname{Li}(\uparrow), \operatorname{Pb}(\uparrow), \mathrm{V}(\uparrow), \mathrm{Zn}(\downarrow)$, where arrows indicate an increase $(\uparrow)$ or decrease $(\downarrow)$ of the metal content in the biosubstrate compared to control. We observed the similar shifts in $18.1 \%$ of the control group with $r_{\mathrm{K}-\mathrm{Zn}}=-0.43(\mathrm{p}<0.05)$, compared with those individuals (26.7\%) in which $r_{\mathrm{K}-\mathrm{Zn}}$ was equal to -0.01 . The values of SI noticeably differed in these categories of healthy individuals: in the subgroup with a distinct negative K-Zn bond $(r=$ -0.43 ; $\mathrm{p}<0.05$ ), the SI was 9.17; and in its absence ( $r=-0.01)$, the SI was only 5.18 [11].

However, we still have to answer the following questions:

1) Is it possible to detect quantitative age-related shifts in the MLH of the epidermis, not only in $\mathrm{Na}$ and $\mathrm{K}$ but also in other metals ( $\mathrm{Al}, \mathrm{Cd}, \mathrm{Cr}, \mathrm{Cu}, \mathrm{Fe}, \mathrm{Li}, \mathrm{Pb}, \mathrm{V}, \mathrm{Zn})$ ?

2) How stable (reliable) is the relationship between the characteristic quantitative changes in MLH and the level of synchronization (SI) in the operation of membrane pumps?

3) Is there a connection between the SI values, quantitative changes in MLH, and the magnitude of the NO signal of EPR spectroscopy of hair?

The results of studies undertaken by us to find answers to these and other questions are presented in the article. 


\section{Materials and Methods}

Atomic emission spectrometry of hair was performed at the Center for Biotic Medicine (Moscow) in 300 practically healthy individuals (residents of Moscow and Riga from the age of 1 to 85 years old) to quantify the level in the hair of the following metals: $\mathrm{Na}, \mathrm{K}, \mathrm{Al}, \mathrm{Cd}, \mathrm{Cr}, \mathrm{Cu} \mathrm{Fe}, \mathrm{Li}, \mathrm{Pb}, \mathrm{V}$, and $\mathrm{Zn}$. Material sampling was carried out with the obligatory and voluntary consent of the subjects in accordance with the ethical standards laid down in 1964 Helsinki Declaration and subsequent amendments thereto. Hair samples were washed first with acetone, then with deionized water three times, followed by air drying at $\mathrm{t}^{\circ}=60^{\circ} \mathrm{C}$. Further sample preparation was carried out using microwave decomposition. For this, hair samples weighing $50 \mathrm{mg}$ were placed in a Teflon container with the addition of $5 \mathrm{ml}$ of concentrated analytical grade $\mathrm{HNO}_{3}$ (Sigma-Aldrich Co, St. Louis, MO, USA). Decomposition was carried out in a Berghof Speedwave 4 system (Berghof Products \& Instruments, Germany) for 20 minutes at $t^{\circ}=170-180^{\circ} \mathrm{C}$.

After decomposition, deionized water was added to a final volume of $15 \mathrm{ml}$. The metal level in the hair was evaluated using inductively coupled plasma mass spectrometry (ICP-MS) NexION 300D (Perkin Elmer Inc., Shelton, CT, USA) using Dynamic Reaction Cell technology with an ESI SC-2 DX4 autosampler (Elemental Scientific INC., Omaha, NE, USA). All individuals (depending on age) were divided into 3 groups of 100 people each: Group I: 1 to 19 year-olds (57 women, 43 men); Group II: 20 to 33 year-olds (79 women, 21 men); Group III: 58 to 85 year-olds (76 women, 24 men). In each group, the metal content in the hair and the degree of synchronization (SI) were measured using spectrometry according to the previously proposed technique [11], and the linear correlation coefficient (Pearson) between the content of $\mathrm{K}$ and $\mathrm{Zn}$ in the hair $\left(r_{\mathrm{K}-\mathrm{Zn}}\right)$ was found.

In addition, along with atomic emission spectrometry and determination of SI, EPR analysis of hair was performed to measure the level of NO production by the method used in our previous studies [6] involving 58 Chernobyl liquidators (55 men and 3 women) and 58 healthy subjects (18 men and 40 women).

Then, a comparative analysis of the magnitude of the NO signal on the EPR spectrogram, spectrometry data, and SI was performed in the Chernobyl group and the control group. It should be emphasized that the age medians in the compared groups almost coincided (Me1 $=53$ years; Me2 $=54$ years, resp.). Using the methods of mathematical statistics, we analyzed the results of hair spectrometry for the content of $\mathrm{Al}, \mathrm{Cd}, \mathrm{Pb}, \mathrm{V}, \mathrm{Li}$, and $\mathrm{Cr}$ obtained from 10,000 healthy subjects: Moscow residents $(5,000$ men and 5,000 women) aged 20 to 45 . To identify the power-law relationship between the metal content in the epidermis and the number of individuals (a sign of self-organized criticality), the probability density (distribution) function (PDF) was estimated and the distribution was adjusted using the method of linearization. We used a similar mathematical approach in our previous study [10]. For statistical data processing, the MATLAB software package was used.

\section{Results and Discussion}

As already mentioned, the power-law dependence takes the form of a straight line on a double logarithmic scale. Therefore, appropriate plots were constructed to determine the power-law relationship between the metal content $(\mathrm{Al}, \mathrm{Cd}, \mathrm{Pb}, \mathrm{V}, \mathrm{Li}$, and $\mathrm{Cr}$ ) in the epidermis and the number of individuals in a given range of numerical values. Graphical evidence of the existence of a powerlaw bond in MLH of such metals as $\mathrm{Na}, \mathrm{K}, \mathrm{Cu}, \mathrm{Fe}$, and $\mathrm{Zn}$ are not given in this article since they were published earlier $[1,10]$.

The probability density of a power-law distribution is determined by the following formula:

$$
p_{k, m}(x)=\frac{k m^{k}}{x^{k+1}}
$$

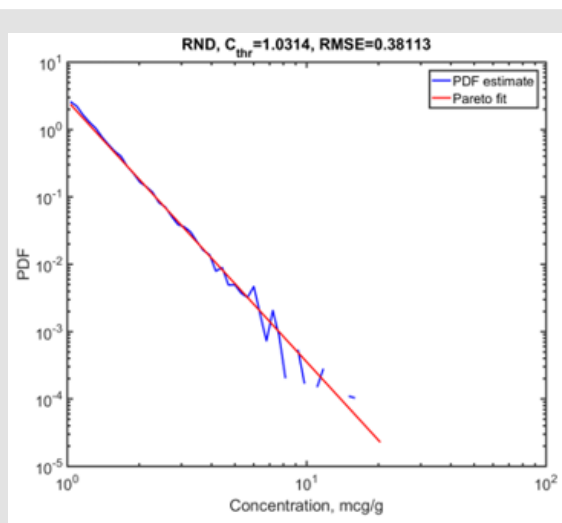

Figure 1: An "ideal" random fit case with a Pareto distribution (RND). The blue curve is the density estimate from spectrometry data. The red curve is the fitting of the power-law distribution by linearization. RMSE is the root mean square error. Cthr is the lowest concentration at which fitting begins. 
To be able to judge about the quality of the fit, an 'ideal' case of such a fit in random numbers with the Pareto distribution is shown below (Figure 1). To obtain a normalized histogram, the column boundaries were chosen uniformly on a logarithmic scale (30 columns for 10,000 measurements). Indicated above the figures are metal name, RMSE is the standard error, $C_{t h r}$ is the lowest concentration with which the fitting begins (concentration values lower than $C_{t h r}$ are not considered). The calculation of the distribution density parameters is presented in Table 1.

Table 1: Calculated power-law density parameters (PDF).

\begin{tabular}{|c|c|c|}
\hline Metal & $\mathbf{k}$ & $\mathbf{~}$ \\
\hline $\mathrm{Al}$ & 3.8732 & 1.6431 \\
\hline $\mathrm{Cd}$ & 3.2382 & 0.12128 \\
\hline $\mathrm{Cr}$ & 4.1316 & 0.37425 \\
\hline $\mathrm{Li}$ & 3.4403 & 0.11465 \\
\hline $\mathrm{Pb}$ & 3.3006 & 0.43318 \\
\hline $\mathrm{V}$ & 4.5955 & 0.1508 \\
\hline $\mathrm{RND}$ & 5.0046 & 0.90352 \\
\hline
\end{tabular}

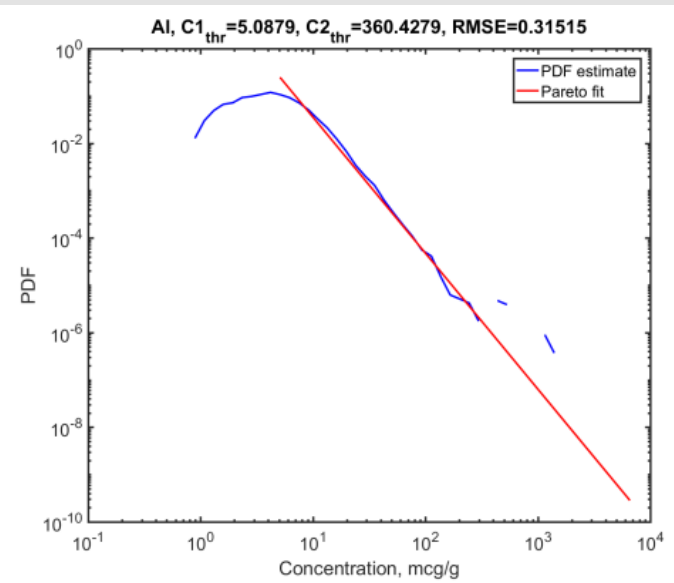

Figure 2: Evaluation of the density and linearization of the power-law distribution for aluminium (Al); designations are the same as in Figure 1.

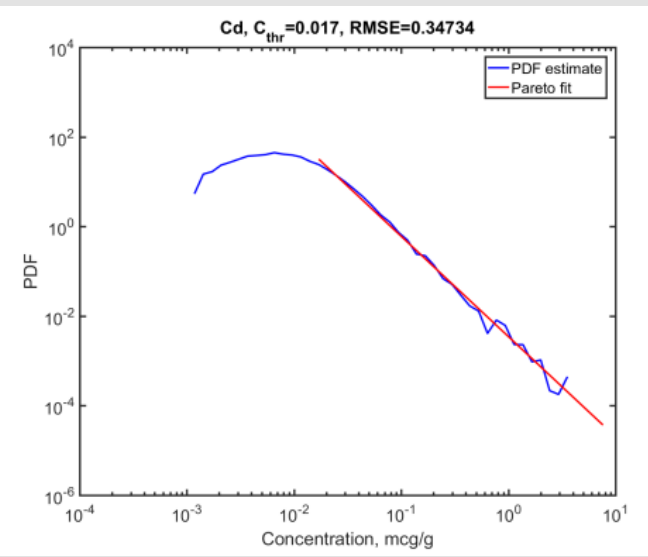

Figure 3: Evaluation of the density and linearization of the power-law distribution for cadmium (Cd); designations are the same as in Figure 1. 


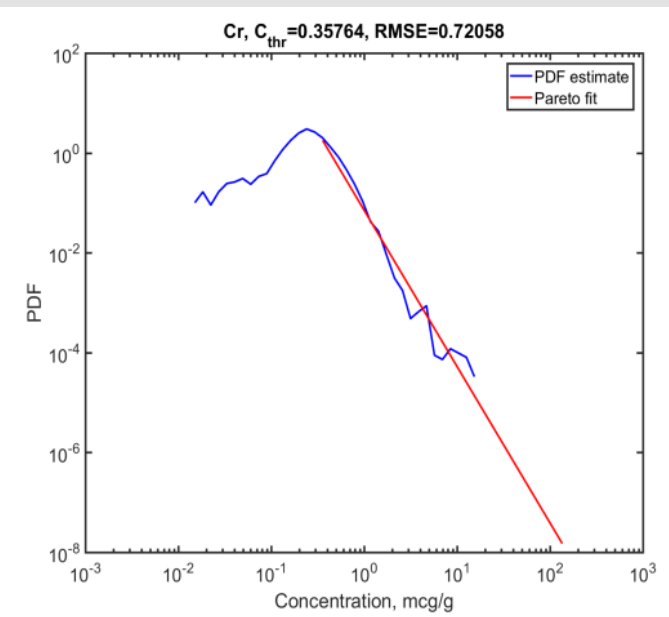

Figure 4: Evaluation of the density and linearization of the power-law distribution for chromium (Cr); designations are the same as in Figure 1.

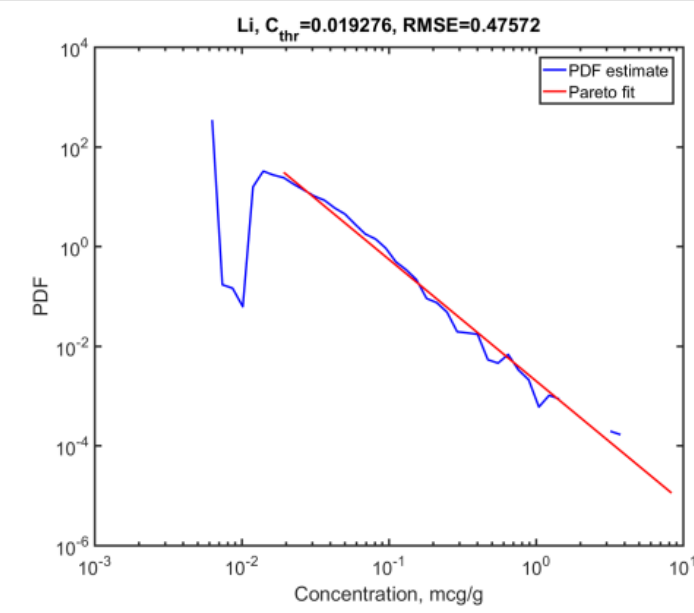

Figure 5: Evaluation of the density and linearization of the power-law distribution for lithium (Li); designations are the same as in Figure 1.

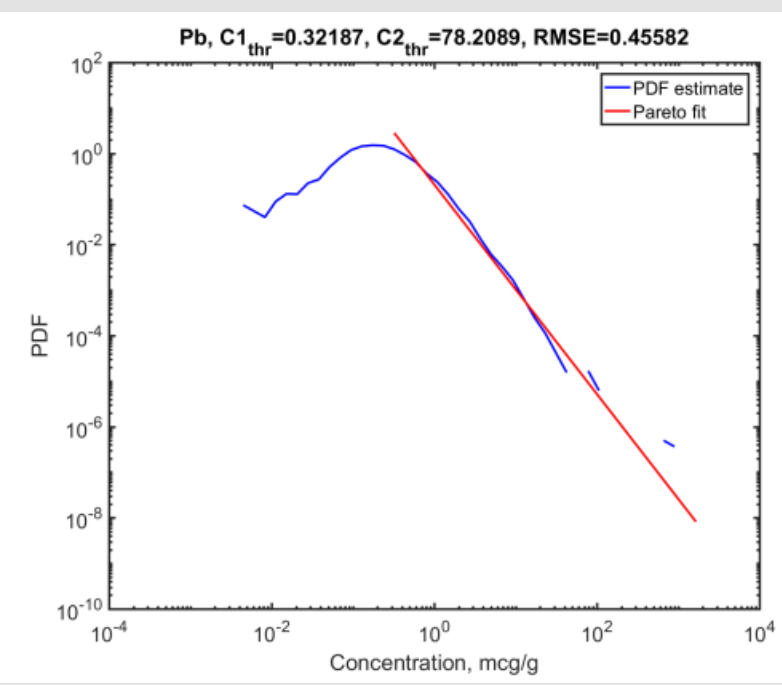

Figure 6: Evaluation of the density and linearization of the power-law distribution for lead $(\mathrm{Pb})$; designations are the same as in Figure 1. 


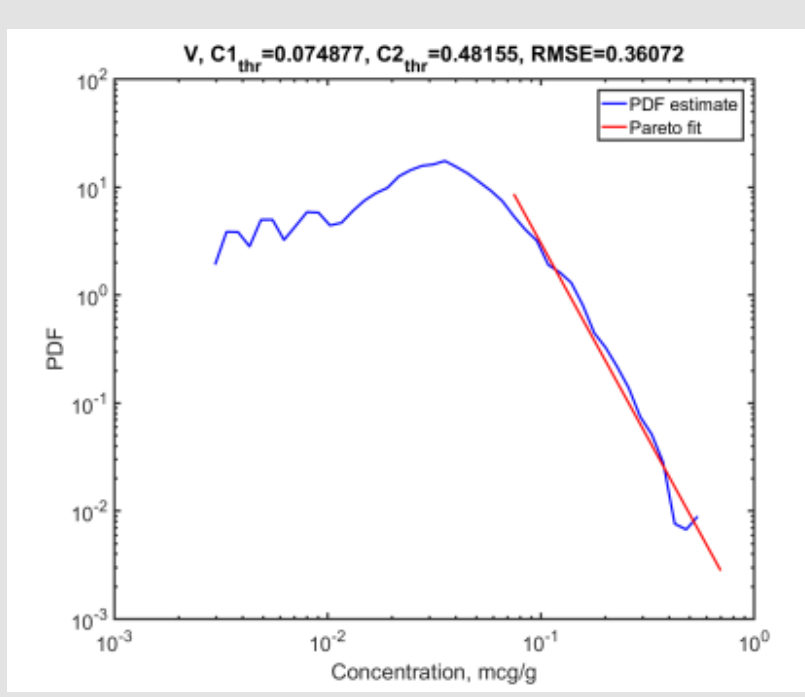

Figure 7: Evaluation of the density and linearization of the power-law distribution for vanadium (V); designations are the same as in Figure 1.

One can get an idea of the size of the critical phase in the homeostasis of one or another metal by the percentage of individuals in the total sample who show reliable graphic signs of criticality. The results of this assessment are shown in Table 2.

Table 2: The proportion of healthy individuals in the total sample ( $n=10000$ ) with MLH in the critical phase for different metals.

\begin{tabular}{|c|c|}
\hline Metal & $\begin{array}{c}\text { Proportion of healthy individ- } \\
\text { uals (\%) in the total sample } \\
(\mathbf{n = 1 0 0 0 0 )} \text { with MLH in a critical } \\
\text { phase }\end{array}$ \\
\hline $\mathrm{Al}$ & 59.8 \\
\hline $\mathrm{Cd}$ & 44.7 \\
\hline $\mathrm{Cr}$ & 40 \\
\hline $\mathrm{Cu}$ & 53.9 \\
\hline $\mathrm{Fe}$ & 58.9 \\
\hline $\mathrm{K}$ & 77.6 \\
\hline $\mathrm{Li}$ & 44.3 \\
\hline $\mathrm{Na}$ & 72.3 \\
\hline $\mathrm{Pb}$ & 62.5 \\
\hline $\mathrm{V}$ & 22.9 \\
\hline $\mathrm{Zn}$ & 50.6 \\
\hline
\end{tabular}

As shown in Table 2, the critical phase in $\mathrm{K}$ and $\mathrm{Na}$ homeostasis is noticeably greater than that of other metals $(77.6 \%$ and $72.3 \%$, resp.). Perhaps this should explain the high and independent of the sample size $r_{\mathrm{K}-\mathrm{Na}}(0.8-0.9)$ when it is separately determined in groups with $\mathrm{Na} / \mathrm{K}<1$ and $\mathrm{Na} / \mathrm{K}>1$ [8]. The smallest critical phase size $(22.9 \%)$ was for vanadium (Figure 7$)$. For other metals, the values of this indicator ranged from $40 \%(\mathrm{Cr})$ to $62.5 \%(\mathrm{~Pb})$. This coincides with the results of our earlier analysis of linear bonds (Pearson), which revealed the unstable (and dependent from sample size) nature of all pair correlations among these metals, with the exception of $\mathrm{K}$ and $\mathrm{Na}$ [9]. The data of hair spectrometry in the study of MLH, the values of SI and $r_{\text {K-Zn }}$ (Pearson) in healthy individuals $(\mathrm{n}=300)$ in different age groups are presented in Table 3.

As follows from Table 3, the quantitative shifts in the extreme age groups (I and III) relative to Group II coincided in their direction not only for $\mathrm{K}$ and $\mathrm{Na}$, but also for all other metals: $\mathrm{Al}(\uparrow), \mathrm{Cd}(\uparrow), \mathrm{Fe}$ $(\uparrow), \operatorname{Cr}(\uparrow), \operatorname{Cu}(\downarrow), \operatorname{Li}(\uparrow), \operatorname{Pb}(\uparrow), V(\uparrow), \operatorname{Zn}(\downarrow)$. Moreover, the SI values in Groups I and III are visibly higher than in Group II (12.6 and 12.05 vs 9.5 resp.). It is significant that the direction of quantitative changes in MLH in this case (Table 3): [K ( $\uparrow), \mathrm{Na}(\uparrow), \mathrm{Al}(\uparrow), \mathrm{Cd}(\uparrow)$, Fe $(\uparrow), \operatorname{Cr}(\uparrow), \operatorname{Cu}(\downarrow), \operatorname{Li}(\uparrow), \operatorname{Pb}(\uparrow), V(\uparrow), \mathrm{Zn}(\downarrow)]$ completely coincides with that of the Chernobyl liquidators $(n=954)$ in relation to control ( $n=947)$ [4]. The value of SI in the general group of liquidators, as already mentioned, was also visibly higher than that of healthy individuals (6.13 vs 2.17) [11]. The dynamics of the coefficient $r_{\mathrm{K}-\mathrm{Zn}}$ (Pearson) is also of interest: $r_{\mathrm{K}-\mathrm{Zn}}$ in Groups I and III was not only twice as high (in absolute value), but also retained its sign (-) in contrast to Group II, see Table 3 ( -0.3 and -0.32 vs 0.16 resp). It was of interest to find out using EPR analysis whether there is a relationship between the detected quantitative shifts in MLH: [K $(\uparrow), \operatorname{Na}(\uparrow), \operatorname{Al}(\uparrow), \operatorname{Cd}(\uparrow), \operatorname{Fe}(\uparrow), \operatorname{Cr}(\uparrow), \operatorname{Cu}(\downarrow), \operatorname{Li}(\uparrow), \operatorname{Pb}(\uparrow), \mathrm{V}(\uparrow), \mathrm{Zn}$ $(\downarrow)]$ and the production of nitric oxide (NO) in biosubstrate (hair). The degree of NO production we estimated by the magnitude of the NO signal in the EPR spectrogram. The results are presented in Table 4. 
Table 3: Median (Me) level of metals in the epidermis, synchronization index (SI) and K-Zn correlation (Pearson) in different age groups in healthy individuals.

\begin{tabular}{|c|c|c|c|}
\hline Metal & $\begin{array}{c}\text { Group I (n=100) } \\
\text { 1 to 19 years old } \\
\text { Me (mcg/g) }\end{array}$ & $\begin{array}{c}\text { Group II } \\
\text { (n=100) } \\
\mathbf{2 0} \text { to 33 } \\
\text { years old } \\
\text { Me (mcg/g) }\end{array}$ & $\begin{array}{c}\text { Group III } \\
\text { (n=100) } \\
\text { 58 to 85 years } \\
\text { old } \\
\text { Me (mcg/g) }\end{array}$ \\
\hline $\mathrm{Al}$ & 6.6 & 3 & 4.7 \\
\hline $\mathrm{Cd}$ & 0.02 & 0.01 & 0.03 \\
\hline $\mathrm{Cr}$ & 0.37 & 0.3 & 0.41 \\
\hline $\mathrm{Cu}$ & 11.3 & 13.8 & 11.5 \\
\hline $\mathrm{Fe}$ & 13.5 & 10.8 & 14 \\
\hline $\mathrm{K}$ & 161.2 & 27.9 & 135.6 \\
\hline $\mathrm{Li}$ & 0.02 & 0.01 & 0.02 \\
\hline $\mathrm{Na}$ & 229.3 & 116.3 & 344.8 \\
\hline $\mathrm{Pb}$ & 0.58 & 0.35 & 0.59 \\
\hline $\mathrm{V}$ & 0.06 & 0.04 & 0.05 \\
\hline $\mathrm{Zn}$ & 155.2 & 193.8 & 176.4 \\
\hline $\mathrm{SI}($ Sync Index) & 12.6 & 9.5 & 12.05 \\
\hline $\mathrm{rK}-\mathrm{Zn}(\mathrm{Pearson})$ & -0.3 & 0.16 & -0.32 \\
\hline
\end{tabular}

Table 4: Median (Me) level of metals in the epidermis, synchronization index (SI) and the magnitude of the NO signal in accident liquidators and healthy individuals.

\begin{tabular}{|c|c|c|}
\hline Metal & $\begin{array}{c}\text { Accident Liquidators } \\
\text { (n=58) Me (mcg/g) }\end{array}$ & $\begin{array}{c}\text { Healthy Individuals } \\
(\mathbf{n}=\mathbf{5 8}) \mathbf{M e}(\mathbf{m c g} / \mathbf{g})\end{array}$ \\
\hline $\mathrm{Al}$ & 6.12 & 4.7 \\
\hline $\mathrm{Cd}$ & 0.04 & 0.02 \\
\hline $\mathrm{Cr}$ & 0.46 & 0.2 \\
\hline $\mathrm{Cu}$ & 11.3 & 13.5 \\
\hline $\mathrm{Fe}$ & 14.98 & 11.8 \\
\hline $\mathrm{K}$ & 218 & 213 \\
\hline $\mathrm{Li}$ & 0.08 & 0.06 \\
\hline $\mathrm{Na}$ & 279 & 111.5 \\
\hline $\mathrm{Pb}$ & 0.97 & 0.57 \\
\hline $\mathrm{V}$ & 0.01 & 0.01 \\
\hline $\mathrm{Zn}$ & 160 & 178.5 \\
\hline SI (Synchronization & 12.05 & 8.3 \\
\hline Index) & $34.1^{*}$ & $19.1^{*}$ \\
\hline NO-signal (n.u.) & 53 & 54 \\
\hline Median (Me) of age & & \\
\hline (years) & & \\
\hline
\end{tabular}

Note: *) significance of difference $\mathrm{p}<0.05$.

As Table 4 shows, the quantitative shifts in the MLH of the Chernobyl liquidators (in their direction) for all metals (with the exception of vanadium) are similar to those in the extreme age groups: [K ( $\uparrow), \mathrm{Na}(\uparrow), \operatorname{Al}(\uparrow), \mathrm{Cd}(\uparrow), \mathrm{Fe}(\uparrow), \mathrm{Cr}(\uparrow), \mathrm{Cu}(\downarrow), \mathrm{Li}(\uparrow)$, $\mathrm{Pb}(\uparrow), \mathrm{Zn}(\downarrow)]$ (Table 3). At the same time, the magnitude of the SI (12.05 vs 8.3) and the degree of NO production in the biosubstrate (34.1 vs 19.1) among the liquidators were significantly higher than in the control (Table 4). To explain the data obtained, it is advisable to use the basic principles of the theory of self-organized criticality, according to which membrane pumps - ATPases (P-type), which carry out the traffic of metals in the epidermis, (being oscillators) are capable of self-organization or transition to a critical (synchronous) mode of operation. The role of activators of these pumps can be played by ROS and RNS, in particular, NO or, more precisely, its derivatives: ions of nitrosonium $\left(\mathrm{NO}^{+}\right)$and of nitroxyl (NO-). An increase in the production of ROS and RNS in the epidermis should inevitably lead to an increase in the density (quantity) of activated ATPases (P-type) on the cell membrane, thereby contributing to the self-starting of the synchronization process.

It cannot be excluded that for the normal functioning of ATPdependent membrane pumps, it is the synchronization mode (as a special case of a critical condition) that is the main regulatory (controlling) mechanism of MLH. Graphical confirmation of the power-law (fractal) distribution of hair spectrometry data (as evidence of criticality) allows us to attribute MLH in the epidermis to SC phenomena that are widespread in living systems. This conclusion has not only theoretical but also practical significance. The fact is that in most publications on hair spectrometry one can come across the strong conviction of the authors that in order to assess the elemental status of the whole body (for example, the availability of metals) it is sufficient to know the mineral composition of hair (spectrometry). However, is it really so? If hair spectrometry data at the level of individuals demonstrates powerlaw distribution, then due to the inherent power-law to scale invariance a similar distribution should be expected at the cellular level.

Membrane pumps, operating in a critical mode, are apparently the main reason for the power-law distribution of metals between individual cells. At the same time, most of these cells have a relatively low metal content, while the number of cells containing metal in high and ultra-high quantities will be much smaller. A similar pattern can be observed in the classic SC model, a 'sand pile', when careful (minimal amount) addition of grains of sand leads to 'avalanches' (critical state). Moreover, most of these avalanches are small and medium in size (while the number of large avalanches is much less). It is significant that there is power-law dependence between the number and the size of avalanches. It should be noted that there are more signs of similarity between the 'sand pile' model and the homeostasis of metals in the epidermis than it may seem at first glance. In both cases we are talking about the events of the socalled 'phase transition' in open dynamical systems on the border of Chaos and Order, when antientropic energy-consuming systems are trying to preserve: in one case (sand pile) - its structural ordering, and in the other (epidermis) metal-ligand homeostasis.

Anti-entropic factors in a sand pile include the weight of sand grains and the strength of their adhesion (rest friction), while in the epidermis these are ATP-dependent membrane pumps working 
against an electrochemical gradient. The power-law (fractal) nature of the distribution of metals at the level of individuals, as already mentioned, should remain as such at the cellular level as well. Therefore, the predominance of individuals with a small and medium level of metals (according to hair spectrometry), with the existing power-law relationship between the metal content and the number of individuals, is explained by the features of the powerlaw distribution itself which does not depend on the level of this metal in the whole body. Figuratively speaking, the power law in the 'sand pile' model works in a critical state regardless of the size of grains of sand (or the size of the sand pile). Therefore, a similar independence of the results of hair spectrometry from the total metal content in the body should be expected in the MLH of the epidermis.

If we are talking about factors capable of influencing MLH in one way or another, then it is necessary to mention: the metal-binding sites of ATP-pumps (TM-MBS), chaperone proteins, transport and depo proteins (RyR1, RyR2, Atox1, CCS, Cox17, metallothioneins, transferrin, ferritin), as well as other ligands, binding with which is necessary to prevent the destructive effect of free metal ions on cellular structures. However, the role of these factors in the events of MLH (in comparison with the power law) is hardly decisive. As follows from Table 4, the critical mode of operation of membrane pumps was found in $72.3 \%$ and $77.6 \%$ of individuals for $\mathrm{Na}$ and $\mathrm{K}$, and in $48.6 \%$ (on average) for other metals. This indicates a significant (and in some cases dominant) influence of criticality (synchronization) on the processes of MLH in the epidermis.

\section{Conclusion}

1) MLH of the epidermis in extreme age groups (1-19 yearolds and 58-85 year-olds) has visible differences compared with that in 20-33 year-olds. These are quantitative shifts in the MLH of extreme age groups that coincide in their direction with respect to the middle age group (20-33 years): [K ( $\uparrow), \mathrm{Na}$ $(\uparrow), \operatorname{Al}(\uparrow), \operatorname{Cd}(\uparrow), \operatorname{Fe}(\uparrow) \operatorname{Cr}(\uparrow), \operatorname{Cu}(\downarrow), \operatorname{Li}(\uparrow), \operatorname{Pb}(\uparrow), \operatorname{V}(\uparrow), \operatorname{Zn}(\downarrow)]$.

2) Unidirectional quantitative shifts in the MLH of the extreme age groups were accompanied by a higher level of paired linear bonds between the concentration values of metals if we evaluate them (bonds) by the SI value (criticality sign). The dynamics of $r_{\mathrm{K}-\mathrm{Zn}}$ was similar to the dynamics of SI

3) In the observations where the age factor was excluded (comparative analysis was carried out in identical age groups), the results of EPR spectroscopy of the hair confirmed the relationship between NO production and signs of criticality in the operation of membrane pumps: a significant increase of NO production in the epidermis was associated with an increase in SI and characteristic unidirectional shifts in MLH.

4) The concept of MLH in the epidermis as an SC phenomenon makes it impossible to assess the content of any specific metal in the whole body by the level of this metal in the hair (spectrometry).

\section{References}

1. Petukhov VI, Dmitriev EV, Baumane LKH, Skalny AV, Lobanova Yu $\mathrm{N}$ (2016) Electrogenic metals in epidermis: relationship with cell bioenergetics. Insights in Biomed 1(2): 9-14.

2. Kolesnikova LI, Darenskaya MA, Grebenkina LA, Osipova EV, Dolgikh MI, et al. (2013) The state of the antioxidant status of children of different ages. Voprosy Pitaniya 82(4): 27-33.

3. Bak P (1996) How Nature Works. The science of self-organized criticality. Copernicus, New York.

4. Petukhov VI, Dmitriev EV, Kalvinsh I, Baumane LKH, Reste ED, et al. (2011) Metal-ligand homeostasis in epidermic cells of Chernobyl accident liquidators. Vitamins \& Trace Elements 1(2): 1-8

5. Kumerova AO, Lece AG, Skesters AP, Orlikov GA, Seleznev JV, et al. (2000) Antioxidant defence and trace element imbalance in patients with postradiation syndrome: first report on phase I studies. Biol Trace Element Res 77(1): 1-12.

6. Petukhov VI, Baumane LK, Reste ED, Zvagule T, Romanova MA, et al. (2013) Diagnosis of nitrosative stress by quantitative EPR-spectroscopy of epidermal cells. Bull Exp Biol Med 154(6): 734-736.

7. Petukhov VI, Baumane LK, Dmitriev EV, Vanin AF (2015) Nitric oxide and electrogenic metals $(\mathrm{Ca}, \mathrm{Na}, \mathrm{K})$ in epidermic cells. Biomed Khim 61(4): 503-509.

8. Petukhov VI, Dmitriev EV, Baumane LKH, Skalny AV, Lobanova Yu N, et al. (2019) Homeostasis of sodium (Na) and potassium (K) in epidermis as a self-organized criticality phenomenon. Proteomics \& Bioinformatics 2(1): 62-67.

9. Petukhov VI, Dmitriev EV, Kalvins II, Bauman LKH, Shkersers AP, et al. (2007) Correlation analysis of hair spectrometry data: a new approach to assessing elemental homeostasis. Bulletin of OSU 12: 128-135.

10. Petukhov VI, Dmitriev EV, Baumane LKH, Skalny AV, Lobanova Yu N, et al. (2018) Some aspects of regulatory criteria for metal-ligand homeostasis in epidermal cells. Journal of Antioxidant Activity 1(3): 22-32.

11. Petukhov VI, Dmitriev EV, Baumane LKH, Skalny AV, Lobanova Yu N, et al. (2018) Membrane pump operation synchronicity (criticality) in epidermal cells: the possibility of quantifying the level of synchronization. International Journal of Negative Results 1(1): 12-19. 
ISSN: 2574-1241

DOI: 10.26717/BJSTR.2020.28.004667

VI Petukhov. Biomed J Sci \& Tech Res

(c) 9 This work is licensed under Creative (c) Commons Attribution 4.0 License

Submission Link: https://biomedres.us/submit-manuscript.php

$\begin{array}{ll}\text { BIOMEDICAL } & \text { Assets of Publishing with us } \\ \text { RESEARCHES } & \text { - Global archiving of articles } \\ \text { - Immediate, unrestricted online access } & \text { - Rigorous Peer Review Process } \\ & \text { - Authors Retain Copyrights } \\ & \end{array}$

